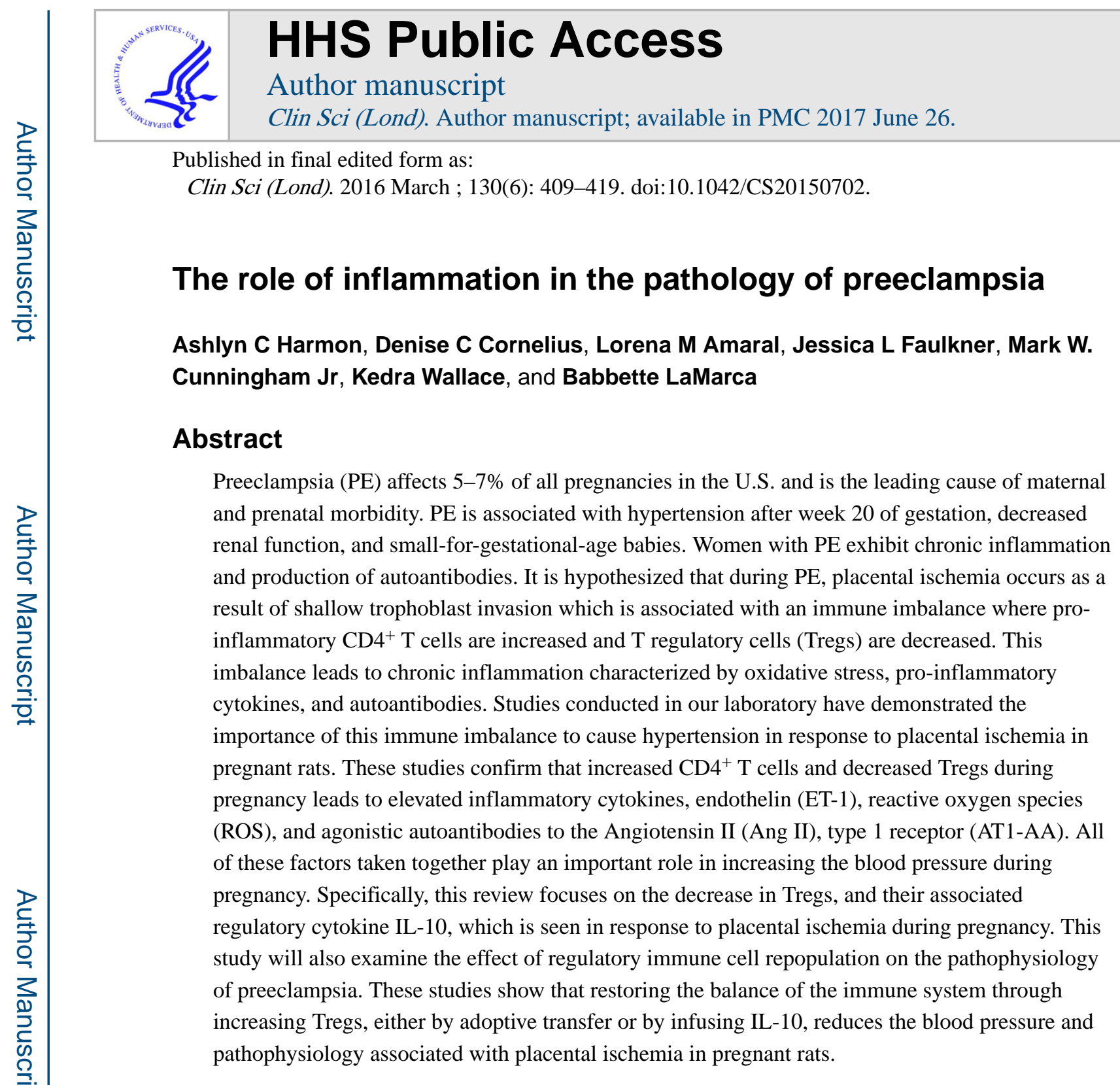

\title{
Preeclampsia: Hypertension During Pregnancy
}

Preeclampsia (PE) affects 5-10\% of pregnant women each year worldwide, while in the United States it accounts for $18 \%$ of maternal deaths each year and is the number one cause of premature births (1). PE is diagnosed by hypertension after week 20 of pregnancy and maybe accompanied by proteinuria and/or edema. According to the National High Blood Pressure Education Program (2), blood pressure of 140/90 $\mathrm{mmHg}$ during pregnancy in women who were not previously hypertensive constitutes a preeclamptic pregnancy (3).

Preeclampsia is a systemic disease that affects the function and health of multiple organs and leads to pathophysiology during pregnancy that affects both the mother and baby. While there is no cure for PE, except for early delivery of the feto-placental unit. The severity of

\footnotetext{
Corresponding author: Babbette LaMarca, Ph.D., Associate Professor, Thesis Director, MFM Fellowship Program, Departments of Pharmacology, Physiology, \& Ob/Gyn, Center for Excellence in Cardiovascular and Renal Research, University of Mississippi Medical Center, Jackson MS 39216.
} 
the pathophysiology associated with PE varies depending the presence of other conditions associated with PE, such as eclampsia, edema, renal failure, liver failure, and HELLP (hemolysis elevated liver low platelet) syndrome (4-6). Women with PE are at high-risk for eclamptic seizures and therefore are given magnesium sulfate for its prevention (7). In severe PE where the systolic blood pressure of the mother is $160-180 \mathrm{mmHg}$ or above and diastolic blood pressure is $105-110 \mathrm{mmHg}$ or higher, intravenous antihypertensive therapy such as hydralazine (vasodilator) or labetalol (beta-blocker) is used to manage the blood pressure(2, 8). Other classes of antihypertensive drugs like angiotensin-converting enzyme (ACE) inhibitors and angiotensin II receptor blockers (ARBs) cannot be used during pregnancy due to their potential teratogenic effects on the fetus (9). Since current treatments for PE are not always effective to improve maternal and fetal outcomes, a greater understanding of the pathogenesis of the disease is necessary so that more effective treatment regimens can be developed.

Much research has been devoted to understanding the causes and mechanisms leading to the development of PE. Despite the many attempts to understand the origins of PE, it remains unknown. However, the importance of the placenta in the development of PE has been well established (10). Evidence supporting the role of the placenta in PE has been presented numerous times, although the exact pathogenesis responsible for altering the placental function is not known (11). Additionally, placentas from preeclamptic women also show vascular abnormalities and inflammation compared to placentas from healthy pregnancies, suggesting a role for inflammation in the disease $(12,13)$.

\section{Placental Ischemia and Immune Imbalance During Preeclampsia}

While the specific mechanisms leading to the development of PE have yet to be elucidated, the proposed mechanism suggests shallow invasion of trophoblast cells leads to decrease in spiral artery remodeling and vascularity of the placenta. The process of trophoblast invasion and spiral artery remodeling during a normal pregnancy, rely heavily on the maternal immune system to properly regulate this important transformation $(14,15)$. During trophoblast invasion, the decidua, which is the lining of the uterus and forms the maternal portion of the placenta, contains a high number of immune cells that are necessary for the proper migration of trophoblast cells (16-18). Macrophages, natural killer (NK) cells, dendritic cells (DCs), T cells, and T regulatory cells (Tregs) are present in the decidua and are required for the normal invasion of trophoblast cells during placentation. These cells infiltrate the decidua and congregate around the trophoblast cells allowing them to reach the endometrium through controlled removal of native cells in the spiral artery (19-22). Uterine NK cells (uNK), macrophages, and DCs together play an integral role in trophoblast invasion and decidual formation $(23,24)$. On the other hand Tregs and regulatory cytokines ensure the proper control and function of pro-inflammatory cells and their actions to ensure proper invasion $(18,25,26)$. In addition, DCs present in the decidua are thought to function to promote a Th2 dominate state in the uterus and placenta in order to induce immunotolerance of the mother to the fetus (27). Together, the immune cells present in the decidua during pregnancy work to ensure proper implantation and to promote trophoblast invasion that is neither shallow nor overly invasive $(14,15)$. This is accomplished through their production of cytokines and angiogenic factors, which are necessary for a normal 
pregnancy. The balance in the number of immune cells present and the factors they produce are crucial for a healthy pregnancy and any imbalance in these local immune responses could potentially result in an malformation of the placenta. Decreases or impaired placental vascularization is a risk factor for complications during pregnancy, such as PE or even loss of the pregnancy $(28,29)$.

During a normal pregnancy there is an increase in the innate immune cell activation in the periphery (30). Cells involved in innate immunity, such as monocytes and granulocytes, are increased in the circulation and show an increase in cell activation during pregnancy (31, 32). Other inflammatory cells, such as DCs and NK cells, are decreased in the periphery during normal pregnancy $(33,34)$. The function of DCs has recently been studied and it was noted that co-stimulatory molecules responsible for DC tolerance are increased during normal pregnancy $(35,36)$.

In contrast to normal pregnancies, pregnancies affected by PE are associated with an improper immune response and milieu of alternately activated immune cells and cytokines $(37,38)$. Placental ischemia, resulting from the insufficient trophoblast invasion seen in PE, has been shown to produce an imbalance in immune function that leads to chronic inflammation and presents similarly to an autoimmune disease $(28,39,40)$. This immune imbalance consists of increased pro-inflammatory immune cells and cytokines, and decreased regulatory immune cells and cytokines, which create a chronic and uncontrolled state of inflammation $(38,41-43)$. This alteration in immune balance is believed to contribute to the overall pathophysiology associated with $\mathrm{PE}$, which includes the production of reactive oxygen species (ROS) $(44,45)$, increased endothelin-1 expression $(10,46-48)$, and B cell production of autoantibodies to the Angiotensin II (AngII) type 1 receptor (AT1AA), which all culminate in the development of hypertension during pregnancy $(1,40,49-$ 52).

\section{Pathophysiology of Preeclampsia \\ Inflammatory Cytokines}

Preeclampsia is associated with chronic immune activation that leads to an increased production of inflammatory cytokines by pro-inflammatory $\mathrm{T}$ cells, and a decrease in regulatory and anti-inflammatory cytokines, which further promotes an inflammatory state during PE (53-56). This imbalance between pro-inflammatory and regulatory cytokines is associated with the placental ischemia that occurs during a preeclamptic pregnancy. This imbalance worsens as the pregnancy progresses (57).

Anti-inflammatory cytokines that help regulate the immune response, like interleukin (IL)-10 and IL-4, play important roles in a normal, successful pregnancy by providing a balance to the immune system (56). Other cytokines, such as tumor necrosis factor alpha (TNF-a), IL-6, and IL-17 which are pro-inflammatory in nature and are usually secreted from activated Th1 and Th17 cells during immunological challenges, promote cytotoxic and inflammatory responses $(47,54,58-61)$. During PE, increased TNF- $a$ and IL-6 are present in the circulation and in the trophoblast cells of the placenta, while IL-10 and IL-4 are 
decreased $(59,62,63)$. This imbalance leads to chronic peripheral and placental inflammation, which plays a role to further complicate the pregnancy.

In the vasculature, increased TNF- $a$ and IL- 6 both contribute to endothelial dysfunction, which is a hallmark feature of PE and is characterized by increased adhesion molecules and endothelial cell permeability $(64,65)$. TNF-a activates endothelial cells, decreases nitric oxide synthase mRNA, and increases the production of the potent vasoconstrictor endothelin-1 by increasing the expression of preproendothelin-1 mRNA $(47,66)$.

Endothelin-1 has been shown in some studies to be increased by 2-3 fold in the circulation of women with PE; expression of its precursor, preproendothelin-1, in tissues of preeclamptic patients is also increased compared to normal pregnant women $(67,68)$. While endothelin-1 levels seen in preeclamptic patients may only be increased around 2-3 times that of normal pregnant patients, the highest levels of endothelin-1 are usually seen during the end of PE, which indicates that the role of endothelin-1 is to promote a further increase in blood pressure rather than initiate hypertension during pregnancy $(10,69)$. The role of endothelin-1 to increase blood pressure during pregnancy was demonstrated in a rat model of $\mathrm{PE}$ where a selective endothelin-1 type $\mathrm{A}\left(\mathrm{ET}_{\mathrm{A}}\right)$ receptor antagonist was administered and resulted in a significant decrease in blood pressure (70).

Oxidative stress occurs as an imbalance in pro- and anti-oxidant factors in the vasculature when the pro-oxidant factors surpass the anti-oxidant factors and leads to the production of ROS. Although usually considered harmful, ROS are generated during normal pregnancy and are required for the progression and development of a healthy pregnancy (71). During this time, antioxidant defenses that scavenge ROS are present to keep a balance between the pro- and anti-oxidant factors involved, which leads to a controlled host defense that protects the mother from the harmful effects of oxidative stress (71). During PE, however, this delicate balance is shifted toward pro-oxidant species and the anti-oxidant defenses are decreased and are insufficient in controlling these pro-oxidant factors, thus resulting in oxidative stress (72-75). This oxidative stress in the placenta contributes to the development of inflammation in the vasculature, which includes the production of inflammatory cytokines TNF-a, IL-6, and IL-17 ultimately leading to a state of endothelial dysfunction through recruitment of immune cells that release oxidative stress molecules (76).

Decreases in nitric oxide (NO) bioavailability is also associated with endothelial dysfunction due to the loss of vasodilator actions. Normal pregnancies are associated with increased nitric oxide production, which leads to changes in the vasculature and vascular/renal hemodynamics necessary for a healthy pregnancy (77-79). In addition, studies have shown that chronic nitric oxide synthase inhibition during pregnancy leads to an increase in total peripheral resistance, which culminates in the development of hypertension and intrauterine growth restriction (80). Thus, it is likely that a decrease in nitric oxide availability due to increased ROS production during PE is contributing to the increased blood pressure seen during the disease.

Expression of adhesion molecules in the vasculature is also increased by TNF- $a$, and both TNF- $a$ and IL-6 lead to increased vascular permeability (81). Placental increases in TNF-a and IL-6, as seen during PE, have been shown to excessively increase the death of 
trophoblast cells and increase endothelial activation (82). Ultimately, these inflammatory cytokines lead to endothelial dysfunction and the vasoconstrictor, endothelin-1, ROS and decreased NO which contribute to the hypertension present during PE $(83,84)$.

\section{Agonistic Autoantibody to the Angiotensin II Receptor}

Another role of TNF- $a$ and IL- 6 and IL-17 that contributes to hypertension during pregnancy is stimulating B cell production of agonistic autoantibody to the Ang II, type 1 receptor (AT1-AA). AT1-AA is produced by stimulated B cells during PE, whereas normal pregnancies have little to no AT1-AA detectable (50-52, 83-87). The renin-angiotensin system (RAS) and its ability to increase blood pressure have been investigated in preeclamptic pregnancies $(88,89)$. The components of the renin-angiotensin system (RAS) are increased during normal pregnancy, but the responsiveness of the vasculature to Ang II is decreased (89). During a preeclamptic pregnancy, women have decreased components of the RAS, and display an increase responsiveness to Ang II $(89,90)$. Heterodimerization of the AngII, type 1 (AT1) receptor occurs more frequently in women with PE and they also have an increased presence of the AT1 receptor in the placenta $(91,92)$.

The presence of AT1-AAs in women with PE has been previously reported (87). This autoantibody was discovered in the sera of preeclamptic patients and found to interact with the Ang II type 1receptor through binding of a seven amino acid stretch of the receptor, which activates the receptor and causes an increase in chronotropic response (87). Purified AT1-AA was shown to activate the AT1 receptor and elicit many effects that are associated with the pathophysiology seen during PE. Activation of the AT1 receptor by the autoantibody has been shown to increase the activation of pro-inflammatory transcription factors in the vasculature and trophoblast cells, which increase the production of TNF- $a$ and ROS $(1,49,85)$. AT1-AA activation of the AT1 receptor also increases vasoconstriction of the renal artery, expression of ET-1, and soluble anti-angiogenic factors, such as soluble fmslike tyrosine kinase-1 (sflt-1), that are associated with PE $(50,93)$. Other studies have demonstrated a role for the AT1-AA in the contribution of hypertension during pregnancy by using an AT1 receptor blocker and B cell depletion to decrease the blood pressure in a rat model of PE (94).

\section{T Lymphocytes During Preeclampsia}

One population of immune cells that is altered and is believed to play a very important role in mediating preeclampsia is T lymphocytes (95-97). Increased production of inflammatory $\mathrm{T}$ cells is accompanied by a reduction in Tregs (98). This imbalance is seen in the circulation of women with PE as well as at the level of the placenta and creates a state of chronic inflammation during preeclamptic pregnancy, which is believed to contribute to the pathogenesis of the disease $(41,42)$. Several subclasses of $\mathrm{CD}^{+} \mathrm{T}$ cells are involved in promoting an inflammatory state during PE. The Th1 and Th17 subclasses are responsible for promoting inflammation during PE, while Tregs and Th2 cells are decreased and therefore unable to properly control the inflammation associated with increased inflammatory T cell populations (99). 
Studies have shown that a healthy pregnancy is associated with a decreased Th1/Th2 profile where Th2 cells are favored in the maternal peripheral circulation for the purpose of immunotolerance to the fetus $(29,56,100-102)$. While this balance is important for pregnancy, other $\mathrm{T}$ lymphocyte subpopulations play a crucial role in pregnancy as well such as the pro-inflammatory Th17 cells (103). Th17 cells are present throughout normal pregnancy and studies have shown that this population of cells increases during late pregnancy and may have a role in contributing to the initiation of labor at term during normal pregnancy (104). Tregs are essential during pregnancy because of their role in promoting immune tolerance through regulation of Th1 from naïve $\mathrm{T}$ cells, along with their ability to secrete IL-10 $(41,95,105,106)$. Both Tregs and IL-10 decrease Th1 cells, which in turn decreases inflammatory cytokines such as IL-6 and TNF-a (103, 105). Low levels of indoleamine 2,3-dioxygenase (IDO) and diminished numbers of Tregs have been reported in the PE placenta $(107,108)$. Indoleamine 2,3-dioxygenase (IDO), an enzyme that mediates the conversion of tryptophan to kynurenine, is known to regulate T-cell activity and an endothelial-derived relaxing factor (107). In a recent study by Santillan et al, mice deficient for IDO (IDO-KO) were generated and evaluated for preeclampsia phenotypes (108). Pregnant IDO-KO mice exhibited renal glomerular endotheliosis, proteinuria, endothelial dysfunction, intrauterine growth restriction, and mildly elevated blood pressure compared to wild-type mice. Collectively these clinical and basic science studies indicate an important role for IDO and TREGS in normal renal function and blood pressure control during pregnancy. Furthermore, these studies demonstrate the importance of maintain a delicate balance between inflammatory and anti-inflammatory cells and cytokines in order to maintain a successful, healthy pregnancy.

A role of inflammatory $\mathrm{T}$ cells in the pathogenesis of $\mathrm{PE}$ has been established through adoptive transfer studies using Th1-like splenocytes. Zenclussen et al. (2004) demonstrated the importance of inflammatory $\mathrm{T}$ cells in a study where splenocytes were isolated from normal pregnant mice then cultured to promote differentiation of Th1-like cells that secreted Th1 specific cytokines (109). Adoptive transfer of these Th1-like cells into normal pregnant mice provoked symptoms of PE including an increase in blood pressure, alterations in kidney function, and increased markers of inflammation in the decidua. Adoptive transfer of the activated Th1-like splenocytes in non-pregnant mice did not result in any changes in immune composition or blood pressure response, demonstrating that a heighted vascular response to Th1-like cells is specific to pregnancy (109).

\section{Reduced Uterine Perfusion Pressure (RUPP) Model of Preeclampsia}

As previously discussed, PE results from improper placentation and trophoblast invasion during pregnancy, which leads to decreased blood flow to the placenta and fetus, creating a state of placental ischemia $(28,110)$. Placental ischemia in pregnant rats, promotes a chronic inflammatory response in the mother which contributes to the pathophysiology of PE, including increased mean arterial blood pressure (MAP), endothelial dysfunction, AT1-AA (87) (111), ET-1, chronic inflammation and oxidative stress and intrauterine growth restriction (46, 112-115). Development of an animal model that recapitulates the disease is vital. The reduced uterine perfusion pressure (RUPP) rat model of PE uses a combination of aortic constriction and occlusion of the uterine-ovarian arteries to decrease blood flow to the 
uterus and create a state of placental ischemia in pregnant rats (116). Although with the RUPP rat we cannot examine mechanisms that lead to impaired trophoblast invasion, we can investigate pathways stimulated in response to placental ischemia that lead to the development of hypertension during pregnancy, since these rats develop a similar pathophysiology as women with PE. Mechanical induction of placental ischemia is performed in pregnant Sprague-Dawley rats. These rats are anesthetized on day 14 of gestation and a surgical procedure is performed to place restrictive silver clips on the abdominal aorta above the iliac bifurcation, and, in order to prevent compensatory blood flow through the ovaries, silver clips are also placed on branches of the ovarian arteries (116, 117). This procedure reduces uteroplacental blood flow by approximately $40 \%$ and increases blood pressure by approximately $20-30 \mathrm{mmHg}$ versus normal pregnant Sprague-Dawley rats (116). These rats also demonstrate characteristics of endothelial dysfunction with a reduction in NO bioavailability (116) and increased contractility of vascular smooth muscle cells (118). Similarly to women with PE, the increase in Ang II receptor activity leads to an increased production of endothelin-1 in renal cortices, placentas, and in the circulation (119). ROS in both placenta and in circulation is increased in RUPP rats versus normal pregnant animals (120). In addition, antiangiogenic factors like sFlt-1 and soluble endoglin (sEng) are increased in RUPP animals, which further lead to decreases in blood supply to the placenta and fetus $(121,122)$.

Placental ischemia in preeclamptic patients leads to increases in inflammatory $\mathrm{T}$ cells and inflammatory cytokines accompanied by decreases in regulatory cells and regulatory cytokines, resulting in a chronic state of inflammation. This imbalance is the basis for the development of PE and we believe it to be responsible for some of the pathophysiology seen during the disease. Therefore, immune alterations associated with PE were validated in RUPP rats to demonstrate that these same imbalances occur in their immune repertoire as a result of placental ischemia. In comparison to normal pregnant rats, RUPP rats exhibit a chronic inflammatory state. An increase in inflammatory $\mathrm{CD}^{+} \mathrm{T}$ cells is seen in these rats along with a decrease in Tregs. Moreover, increased inflammatory cytokines such as TNF-a and IL- 6 and IL-17 are seen in the circulation of RUPP rats, while regulatory cytokines, IL-10 and IL-4, are decreased $(47,58)$.

\section{The Role of $\mathrm{CD4}^{+} \mathrm{T}$ cells stimulated in RUPP rats to cause pathophysiology of PE}

A study done in our lab was designed to test the impact of placental ischemia on $\mathrm{CD}^{+}{ }^{+} \mathrm{T}$ cells and the downstream effects of $\mathrm{CD}^{+}{ }^{+} \mathrm{T}$ cells activation during pregnancy. In order to do so $\mathrm{CD}^{+}{ }^{+} \mathrm{T}$ cells from RUPP rats were adoptively transferred into normal pregnant rats which resulted in the development of many characteristics of PE. Normal pregnant rats that received RUPP CD4 ${ }^{+} \mathrm{T}$ cells had a significant increase in blood pressure, while there was no significant increase in blood pressure seen in the normal pregnant recipients of normal pregnant $\mathrm{CD}^{+} \mathrm{T}$ cells, ruling out an immune rejection response (43). Adoptive transfer of RUPP CD4 ${ }^{+} \mathrm{T}$ cells into normal pregnant rats also led to an increase in circulating inflammatory cytokines TNF-a, IL-6, and IL-17, and sFlt-1, AT1-AAs, ET-1 and ROS. Blood pressure increase in response to RUPP CD4 ${ }^{+} \mathrm{T}$ cells was blocked by Tempol, 
endothelin type A (ETA) receptor blockade and Losartan or Rituximab, for B cell depletion $(94,123)$. These adoptive transfer studies, along with the previously described Th1-like splenocyte study, indicate a strong role for preeclamptic inflammatory $\mathrm{T}$ cells in the development of hypertension during pregnancy, and in promoting the pathophysiology that accompanies the blood pressure increase.

\section{The Effect of Decreased Tregs and IL-10 in Preeclampsia}

Along with increased levels of inflammatory T cells, Tregs are decreased during PE in response to placental ischemia. These cells are identified by the expression of cell surface markers CD4 and CD25 and the specific internal transcription factor forkhead box protein 3 $\left(\right.$ Foxp $\left.^{+}\right)(124)$. Tregs are responsible for suppression of responses by the adaptive and innate immune system and control unwanted immune responses through various mechanisms. Loss of Treg function has been shown to lead to autoimmune diseases and other immunopathology, including maternal loss of tolerance for the fetus during pregnancy (124). Tregs are increased very early in normal pregnancy and reach their highest levels during the second trimester before decreasing back to normal (125). The peak times for Tregs coincides with important processes like vascular remodeling and trophoblast invasion, which are integral to a healthy pregnancy. Without Treg function, immune processes would be chronically shifted towards uncontrolled activation and stimulation of inflammatory $\mathrm{T}$ cells and their secretion of inflammatory cytokines. Therefore, in diseases such as PE, where Tregs and their secretion of IL-10 and TGF- $\beta$ are reduced (126), thereby leaving the stimulation and proliferation of inflammatory $\mathrm{T}$ cells unchecked.

Evidence for reduced Tregs to contribute to PE has been provided by many clinical studies. Tregs have been shown to be decreased both in the circulation and decidua of women with $\mathrm{PE}$, and the decrease in Tregs is directly proportional to the severity of the disease (127). Decreased circulating Tregs has also been seen in women who have had multiple miscarriages (106). Studies have shown that decreases in decidual Tregs causes increased apoptosis in trophoblast cells, preventing sufficient invasion of trophoblasts into the decidua $(128,129)$.

Interleukin-10 is an important anti-inflammatory cytokine that is secreted by Tregs, but the cytokine also stimulates the production of Tregs from naïve T cells (130-132). IL-10 mediates inhibition of Th1 secreted inflammatory cytokines and provides an important balance for inflammation at the fetal-maternal interface (133). An important feedback mechanism exists between IL-10 and Tregs where IL-10 can induce the expression of transcription factor Foxp3, which is necessary for the production of Tregs (134). Other studies have also shown that IL-10 can increase differentiation of Tregs. In one study, naïve $\mathrm{CD}^{+} \mathrm{T}$ cells were incubated with IL-10-producing dendritic cells that promoted the differentiation of IL-10 producing Tregs, highlighting the important feedback mechanism that exists between IL-10 and Tregs (135).

Pro-inflammatory cytokines down-regulated by IL-10 include IFN-y, IL-2, and TNF-a (136, 137). Levels of IL-10 are increased throughout normal pregnancy and first begin to drop when labor begins (138). In addition to Tregs, villous cytotrophoblasts also secrete IL-10 
during pregnancy and the expression of IL-10 (139) and its receptor has been identified on a number of cell types found in the decidua such as trophoblasts, stromal cells, macrophages and uterine NK cells, but it is not clear how IL-10 may influence trophoblast invasion (140). However, the presence of IL-10 at the fetal-maternal interface and its strong antiinflammatory properties are suspected to contribute to allogeneic tolerance of the fetus during normal pregnancy $(63,141-145)$.

During PE, reduced levels of IL-10 have been observed in circulation and in the placenta $(143,146,147)$. Previous studies have demonstrated IL-10 to be a potent cytokine that regulates vasculature function and prevents vascular dysfunction $(131,146)$. IL-10 decreases inflammatory cytokines that are linked to oxidative stress, while promoting vascular healing, a necessary process for spiral artery remodeling and placental perfusion. These functions of IL-10 were shown to lead to a restoration of endothelin-dependent relaxation and increased eNOS expression in endothelin-1 treated aortic rings (148). IL-10 has also been shown to improve characteristics of $\mathrm{PE}$ in pregnant, DOCA/saline rats where investigators noted a decrease in circulating endothelin- 1 and IFN- $\gamma$, restoration of aortic relaxation responses, decreased proteinuria and an improvement in litter size following IL-10 treatment (149).

Our most recent studies demonstrated that adoptive transfer of Tregs from normal pregnant rats into RUPP rats lowered blood pressure, minimized intrauterine growth restriction (IUGR), reduced the inflammatory response with a corresponding increase in antiinflammatory cytokines, significantly decreased ET-1 expression, and placental oxidative stress. Importantly, Tregs also attenuated the production of agonistic AT1-AA (150). These data support a role for decreased Tregs in the pathophysiology of PE. In addition, the supplementation of normal pregnant Tregs prior to the time of induced placental ischemia (gestational day 12) suggests the importance of normal pregnant immune regulation in maintaining lower levels of inflammation, oxidative stress, AT1-AA, and ET-1, all of which are responsible for increasing blood pressure, and may ultimately result in a more normal fetal weight and safer blood pressures in response to placental ischemia.

Based on these studies, it appears that the significantly different cytokine profile seen in RUPP rats can be somewhat improved by increasing the Treg population. Restoring Tregs in RUPP animals also inhibited effector $\mathrm{T}$ cell activation, which may be the mechanism by which inflammation and oxidative stress were lowered (150). Without T-cell activation, inflammatory cytokine production would be decreased. This in turn would result in fewer inflammatory cells and less production of ROS. Again, a very important finding from this study was that adoptive transfer of Tregs inhibited the production of AT1-AA (150), which also could be occurring through prevention of T-cell mediated activation of B cells. Tregs also secrete immunosuppressive factors such as IL-10, which has been suggested by other studies to have direct effects in improving vascular function as well as inhibiting the inflammatory function of effector $\mathrm{CD} 4^{+} \mathrm{T}$ cells. While the exact beneficial mechanism of Treg function needs to be further investigated, it is clear that Tregs play an important role in promoting a normal, healthy pregnancy and may prove to be a useful target for the treatment of PE. 
In order to examine ways to safely increase Tregs during pregnancy we turned to IL-10 supplementation. Therefore, in a separate study, we supplemented IL-10 via osmotic mini pumps to RUPP rats to restore the circulating levels to that of normal pregnant rats (151). IL-10 supplementation lowered the overall number of circulating $\mathrm{CD}^{+} \mathrm{T}$ cells while increasing the population of circulating Tregs to that of normal pregnant rats. In addition to normalizing Tregs, IL-10 supplementation also normalized pro-inflammatory cytokines TNF- $a$ and IL-6 and, importantly, supplementation of IL-10 to RUPP rats significantly lowered AT1-AA, placental ROS and ET-1, which proved beneficial in decreasing blood pressure during pregnancy. Normal pregnant rats supplemented with IL-10 exhibited no changes in circulating inflammatory cytokines nor blood pressure (151).

In addition to these recent findings, our laboratory has previously shown that placental explants from preeclamptic patients secreted lower levels of IL-10 in culture under normal oxygen and hypoxic conditions compared to placental explants from normal pregnant patients (152). Lower levels of IL-10 during preeclampsia would allow for increased T cell activation and differentiation into a pro-inflammatory phenotype, thus, leading to an increased number of inflammatory $\mathrm{T}$ helper cells, cytokines and possibly $\mathrm{B}$ cell stimulation and thus AT1-AAs. In addition, B cell depletion in RUPP rats caused lower AT1-AA and blood pressure in response to placental ischemia, however this technique is not ideal for a growing fetus (153). In our recent study, IL-10 supplementation normalized Tregs and caused significant reductions in AT1-AA in response to placental ischemia. Furthermore, when treated with IL-10, RUPP rats had a significantly lower blood pressure than the untreated RUPP group, although not fully normalized to the degree of normal pregnant rats (151). We have previously shown that two mechanisms of hypertension stimulated by the AT1-AA activation of the AT1 receptor are ET-1 production and placental oxidative stress (85), both of which were reduced in RUPP rats treated with IL-10 (151).

\section{Summary and conclusion}

While the exact mechanisms by which PE occurs still remain unknown, studies investigating the immune imbalance that accompanies and contributes to the progression of the disease are beginning to identify possible targets for treatment. Knowing how different components of the immune system individually affect the progression and development of PE will be useful in developing drugs that are necessary to improve the outcomes of mothers and babies affected by the disease. Not only have studies demonstrated that regulatory immune factors IL-10 and Tregs decrease the pathophysiology of PE, but these studies also suggest that this decrease is largely mediated through AT1-AA reduction, ROS and ET-1. In addition, IL-10 and Tregs also improve the pathophysiology of PE through Th1 regulation and by exhibiting anti-inflammatory effects in general. While it may not be feasible to simply supplement Tregs and IL-10 to mothers with PE due to the immunosuppressive actions, the identification of these two important immune factors and their mechanisms does offer a starting point for developing new therapeutic targets for treatment of this disease.

\section{Acknowledgments}

Sources of support: This work was supported by National Institutes of Health grants HL105324, HL126301, HL124715, HL51971, HL78147, and HD067541. 


\section{LITERATURE CITED}

1. Herse F, LaMarca B. Angiotensin II type 1 receptor autoantibody (AT1-AA)-mediated pregnancy hypertension. American journal of reproductive immunology. 2013; 69(4):413-8. Epub 2013/01/03. [PubMed: 23279165]

2. NHBPEP. Report of the National High Blood Pressure Education Program Working Group on High Blood Pressure in Pregnancy. American journal of obstetrics and gynecology. 2000; 183(1):S1-S22. Epub 2000/08/02.

3. Noris M, Perico N, Remuzzi G. Mechanisms of disease: Pre-eclampsia. Nature clinical practice Nephrology. 2005; 1(2):98-114. quiz 20. Epub 2006/08/26.

4. Keyes LE, Armaza JF, Niermeyer S, Vargas E, Young DA, Moore LG. Intrauterine growth restriction, preeclampsia, and intrauterine mortality at high altitude in Bolivia. Pediatr Res. 2003; 54(1):20-5. Epub 2003/04/18. [PubMed: 12700368]

5. Lachmeijer AM, Arngrimsson R, Bastiaans EJ, Frigge ML, Pals G, Sigurdardottir S, et al. A genome-wide scan for preeclampsia in the Netherlands. Eur J Hum Genet. 2001; 9(10):758-64. Epub 2002/01/10. [PubMed: 11781687]

6. Ghiringhelli F, Menard C, Martin F, Zitvogel L. The role of regulatory T cells in the control of natural killer cells: relevance during tumor progression. Immunol Rev. 2006; 214:229-38. Epub 2006/11/15. [PubMed: 17100888]

7. Witlin AG, Sibai BM. Magnesium sulfate therapy in preeclampsia and eclampsia. Obstetrics and gynecology. 1998; 92(5):883-9. Epub 1998/10/30. [PubMed: 9794688]

8. Sibai BM. Diagnosis and management of gestational hypertension and preeclampsia. Obstetrics and gynecology. 2003; 102(1):181-92. Epub 2003/07/10. [PubMed: 12850627]

9. Sibai BM. Chronic hypertension in pregnancy. Obstetrics and gynecology. 2002; 100(2):369-77. Epub 2002/08/02. [PubMed: 12151166]

10. Granger JP, Alexander BT, Llinas MT, Bennett WA, Khalil RA. Pathophysiology of hypertension during preeclampsia linking placental ischemia with endothelial dysfunction. Hypertension. 2001; 38(3 Pt 2):718-22. Epub 2001/09/22. [PubMed: 11566964]

11. Roberts JM, Gammill HS. Preeclampsia: recent insights. Hypertension. 2005; 46(6):1243-9. Epub 2005/10/19. [PubMed: 16230510]

12. Roberts DJ, Post MD. The placenta in pre-eclampsia and intrauterine growth restriction. J Clin Pathol. 2008; 61(12):1254-60. Epub 2008/07/22. [PubMed: 18641412]

13. Roberts JM, Escudero C. The placenta in preeclampsia. Pregnancy Hypertens. 2012; 2(2):72-83. Epub 2012/06/30. [PubMed: 22745921]

14. Lala PK, Chakraborty C. Factors regulating trophoblast migration and invasiveness: possible derangements contributing to pre-eclampsia and fetal injury. Placenta. 2003; 24(6):575-87. Epub 2003/06/28. [PubMed: 12828917]

15. Wells M. The pathology of gestational trophoblastic disease: recent advances. Pathology. 2007; 39(1):88-96. Epub 2007/03/17. [PubMed: 17365825]

16. King A. Uterine leukocytes and decidualization. Hum Reprod Update. 2000; 6(1):28-36. Epub 2000/03/11. [PubMed: 10711827]

17. Trundley A, Moffett A. Human uterine leukocytes and pregnancy. Tissue Antigens. 2004; 63(1):112. Epub 2003/12/04. [PubMed: 14651517]

18. Williams PJ, Searle RF, Robson SC, Innes BA, Bulmer JN. Decidual leucocyte populations in early to late gestation normal human pregnancy. J Reprod Immunol. 2009; 82(1):24-31. Epub 2009/09/08. [PubMed: 19732959]

19. Herberts C, Melgert B, van der Laan JW, Faas M. New adjuvanted vaccines in pregnancy: what is known about their safety? Expert Rev Vaccines. 2010; 9(12):1411-22. Epub 2010/11/26. [PubMed: 21105777]

20. Lash GE, Robson SC, Bulmer JN. Review: Functional role of uterine natural killer (uNK) cells in human early pregnancy decidua. Placenta. 2010; 31(Suppl):S87-92. Epub 2010/01/12. [PubMed: 20061017] 
21. Nagamatsu T, Schust DJ. The immunomodulatory roles of macrophages at the maternal-fetal interface. Reprod Sci. 2010; 17(3):209-18. Epub 2010/01/13. [PubMed: 20065301]

22. Silva LM, Coolman M, Steegers EA, Jaddoe VW, Moll HA, Hofman A, et al. Low socioeconomic status is a risk factor for preeclampsia: the Generation R Study. Journal of hypertension. 2008; 26(6):1200-8. Epub 2008/05/14. [PubMed: 18475158]

23. Craven CM, Morgan T, Ward K. Decidual spiral artery remodelling begins before cellular interaction with cytotrophoblasts. Placenta. 1998; 19(4):241-52. Epub 1998/06/25. [PubMed: 9639319]

24. Hanna J, Goldman-Wohl D, Hamani Y, Avraham I, Greenfield C, Natanson-Yaron S, et al. Decidual NK cells regulate key developmental processes at the human fetal-maternal interface. Nature medicine. 2006; 12(9):1065-74. Epub 2006/08/08.

25. Somerset DA, Zheng Y, Kilby MD, Sansom DM, Drayson MT. Normal human pregnancy is associated with an elevation in the immune suppressive CD25+CD4+ regulatory T-cell subset. Immunology. 2004; 112(1):38-43. Epub 2004/04/21. [PubMed: 15096182]

26. Tilburgs T, Roelen DL, van der Mast BJ, de Groot-Swings GM, Kleijburg C, Scherjon SA, et al. Evidence for a selective migration of fetus-specific CD4+CD25bright regulatory $\mathrm{T}$ cells from the peripheral blood to the decidua in human pregnancy. Journal of immunology. 2008; 180(8):573745. Epub 2008/04/09.

27. Miyazaki S, Tsuda H, Sakai M, Hori S, Sasaki Y, Futatani T, et al. Predominance of Th2promoting dendritic cells in early human pregnancy decidua. J Leukoc Biol. 2003; 74(4):514-22. Epub 2003/09/10. [PubMed: 12960246]

28. Redman CW, Sargent IL. Immunology of pre-eclampsia. American journal of reproductive immunology. 2010; 63(6):534-43. Epub 2010/03/25. [PubMed: 20331588]

29. Veenstra van Nieuwenhoven AL, Heineman MJ, Faas MM. The immunology of successful pregnancy. Hum Reprod Update. 2003; 9(4):347-57. Epub 2003/08/21. [PubMed: 12926528]

30. Davis D, Kaufmann R, Moticka EJ. Nonspecific immunity in pregnancy: monocyte surface Fcgamma receptor expression and function. J Reprod Immunol. 1998; 40(2):119-28. Epub 1999/01/09. [PubMed: 9881740]

31. Luppi P, Haluszczak C, Betters D, Richard CA, Trucco M, DeLoia JA. Monocytes are progressively activated in the circulation of pregnant women. J Leukoc Biol. 2002; 72(5):874-84. Epub 2002/11/14. [PubMed: 12429709]

32. Naccasha N, Gervasi MT, Chaiworapongsa T, Berman S, Yoon BH, Maymon E, et al. Phenotypic and metabolic characteristics of monocytes and granulocytes in normal pregnancy and maternal infection. American journal of obstetrics and gynecology. 2001; 185(5):1118-23. Epub 2001/11/22. [PubMed: 11717644]

33. Shin S, Jang JY, Roh EY, Yoon JH, Kim JS, Han KS, et al. Differences in circulating dendritic cell subtypes in pregnant women, cord blood and healthy adult women. J Korean Med Sci. 2009; 24(5):853-9. Epub 2009/10/02. [PubMed: 19794983]

34. Ueda Y, Hagihara M, Okamoto A, Higuchi A, Tanabe A, Hirabayashi K, et al. Frequencies of dendritic cells (myeloid DC and plasmacytoid DC) and their ratio reduced in pregnant women: comparison with umbilical cord blood and normal healthy adults. Hum Immunol. 2003; 64(12): 1144-51. Epub 2003/11/25. [PubMed: 14630396]

35. Miwa N, Hayakawa S, Miyazaki S, Myojo S, Sasaki Y, Sakai M, et al. IDO expression on decidual and peripheral blood dendritic cells and monocytes/macrophages after treatment with CTLA-4 or interferon-gamma increase in normal pregnancy but decrease in spontaneous abortion. Molecular human reproduction. 2005; 11(12):865-70. Epub 2006/01/20. [PubMed: 16421220]

36. von Rango U, Krusche CA, Beier HM, Classen-Linke I. Indoleamine-dioxygenase is expressed in human decidua at the time maternal tolerance is established. J Reprod Immunol. 2007; 74(1-2): 34-45. Epub 2007/02/27. [PubMed: 17321596]

37. Freeman DJ, McManus F, Brown EA, Cherry L, Norrie J, Ramsay JE, et al. Short- and long-term changes in plasma inflammatory markers associated with preeclampsia. Hypertension. 2004; 44(5):708-14. Epub 2004/09/29. [PubMed: 15452036]

38. LaMarca B, Cornelius D, Wallace K. Elucidating immune mechanisms causing hypertension during pregnancy. Physiology. 2013; 28(4):225-33. Epub 2013/07/03. [PubMed: 23817797] 
39. Cornelius DC, Hogg JP, Scott J, Wallace K, Herse F, Moseley J, et al. Administration of interleukin-17 soluble receptor C suppresses TH17 cells, oxidative stress, and hypertension in response to placental ischemia during pregnancy. Hypertension. 2013; 62(6):1068-73. Epub 2013/09/26. [PubMed: 24060899]

40. Irani RA, Zhang Y, Zhou CC, Blackwell SC, Hicks MJ, Ramin SM, et al. Autoantibody-mediated angiotensin receptor activation contributes to preeclampsia through tumor necrosis factor-alpha signaling. Hypertension. 2010; 55(5):1246-53. Epub 2010/03/31. [PubMed: 20351341]

41. Prins JR, Boelens HM, Heimweg J, Van der Heide S, Dubois AE, Van Oosterhout AJ, et al. Preeclampsia is associated with lower percentages of regulatory T cells in maternal blood. Hypertension in pregnancy. 2009; 28(3):300-11. Epub 2009/05/05. [PubMed: 19412837]

42. Santner-Nanan B, Peek MJ, Khanam R, Richarts L, Zhu E, Fazekas de St Groth B, et al. Systemic increase in the ratio between Foxp3+ and IL-17-producing CD4+ T cells in healthy pregnancy but not in preeclampsia. Journal of immunology. 2009; 183(11):7023-30. Epub 2009/11/17.

43. Wallace K, Richards S, Dhillon P, Weimer A, Edholm ES, Bengten E, et al. CD4+ T-helper cells stimulated in response to placental ischemia mediate hypertension during pregnancy. Hypertension. 2011; 57(5):949-55. Epub 2011/04/06. [PubMed: 21464392]

44. Conrad KP, Benyo DF. Placental cytokines and the pathogenesis of preeclampsia. American journal of reproductive immunology. 1997; 37(3):240-9. Epub 1997/03/01. [PubMed: 9127646]

45. Dhillion P, Wallace K, Herse F, Scott J, Wallukat G, Heath J, et al. IL-17-mediated oxidative stress is an important stimulator of AT1-AA and hypertension during pregnancy. American journal of physiology Regulatory, integrative and comparative physiology. 2012; 303(4):R353-8. Epub 2012/06/22.

46. Granger JP, Alexander BT, Llinas MT, Bennett WA, Khalil RA. Pathophysiology of preeclampsia: linking placental ischemia/hypoxia with microvascular dysfunction. Microcirculation. 2002; 9(3): 147-60. Epub 2002/06/25. [PubMed: 12080413]

47. LaMarca BB, Cockrell K, Sullivan E, Bennett W, Granger JP. Role of endothelin in mediating tumor necrosis factor-induced hypertension in pregnant rats. Hypertension. 2005; 46(1):82-6. Epub 2005/06/02. [PubMed: 15928030]

48. LaMarca BD, Alexander BT, Gilbert JS, Ryan MJ, Sedeek M, Murphy SR, et al. Pathophysiology of hypertension in response to placental ischemia during pregnancy: a central role for endothelin? Gender medicine. 2008; 5(Suppl A):S133-8. Epub 2008/05/28. [PubMed: 18395679]

49. LaMarca B, Wallace K, Granger J. Role of angiotensin II type I receptor agonistic autoantibodies (AT1-AA) in preeclampsia. Curr Opin Pharmacol. 2011; 11(2):175-9. Epub 2011/02/15. [PubMed: 21317038]

50. Parrish MR, Ryan MJ, Glover P, Brewer J, Ray L, Dechend R, et al. Angiotensin II type 1 autoantibody induced hypertension during pregnancy is associated with renal endothelial dysfunction. Gender medicine. 2011; 8(3):184-8. Epub 2011/05/24. [PubMed: 21600854]

51. Wenzel K, Rajakumar A, Haase H, Geusens N, Hubner N, Schulz H, et al. Angiotensin II type 1 receptor antibodies and increased angiotensin II sensitivity in pregnant rats. Hypertension. 2011; 58(1):77-84. Epub 2011/05/18. [PubMed: 21576625]

52. Zhou CC, Ahmad S, Mi T, Abbasi S, Xia L, Day MC, et al. Autoantibody from women with preeclampsia induces soluble Fms-like tyrosine kinase-1 production via angiotensin type 1 receptor and calcineurin/nuclear factor of activated T-cells signaling. Hypertension. 2008; 51(4): 1010-9. Epub 2008/02/09. [PubMed: 18259044]

53. Bennett WA, Lagoo-Deenadayalan S, Stopple JA, Barber WH, Hale E, Brackin MN, et al. Cytokine expression by first-trimester human chorionic villi. American journal of reproductive immunology. 1998; 40(5):309-18. Epub 1998/12/31. [PubMed: 9870073]

54. Formby B. Immunologic response in pregnancy. Its role in endocrine disorders of pregnancy and influence on the course of maternal autoimmune diseases. Endocrinol Metab Clin North Am. 1995; 24(1):187-205. Epub 1995/03/01. [PubMed: 7781626]

55. Hanna N, Hanna I, Hleb M, Wagner E, Dougherty J, Balkundi D, et al. Gestational age-dependent expression of IL-10 and its receptor in human placental tissues and isolated cytotrophoblasts. Journal of immunology. 2000; 164(11):5721-8. Epub 2000/05/23. 
56. Wegmann TG, Lin H, Guilbert L, Mosmann TR. Bidirectional cytokine interactions in the maternal-fetal relationship: is successful pregnancy a TH2 phenomenon? Immunol Today. 1993; 14(7):353-6. Epub 1993/07/01. [PubMed: 8363725]

57. Lamarca B. The role of immune activation in contributing to vascular dysfunction and the pathophysiology of hypertension during preeclampsia. Minerva ginecologica. 2010; 62(2):105-20. Epub 2010/05/27. [PubMed: 20502423]

58. Gadonski G, LaMarca BB, Sullivan E, Bennett W, Chandler D, Granger JP. Hypertension produced by reductions in uterine perfusion in the pregnant rat: role of interleukin 6. Hypertension. 2006; 48(4):711-6. Epub 2006/08/31. [PubMed: 16940225]

59. Keiser SD, Veillon EW, Parrish MR, Bennett W, Cockrell K, Fournier L, et al. Effects of 17hydroxyprogesterone on tumor necrosis factor-alpha-induced hypertension during pregnancy. American journal of hypertension. 2009; 22(10):1120-5. Epub 2009/09/12. [PubMed: 19745821]

60. Lamarca B, Speed J, Ray LF, Cockrell K, Wallukat G, Dechend R, et al. Hypertension in response to IL-6 during pregnancy: role of AT1-receptor activation. Int J Infereron Cytokine Mediator Res. 2011; 2011(3):65-70. Epub 2012/09/25. [PubMed: 23002372]

61. Zhou CC, Irani RA, Dai Y, Blackwell SC, Hicks MJ, Ramin SM, et al. Autoantibody-mediated IL-6-dependent endothelin-1 elevation underlies pathogenesis in a mouse model of preeclampsia. Journal of immunology. 2011; 186(10):6024-34. Epub 2011/04/13.

62. Arriaga-Pizano L, Jimenez-Zamudio L, Vadillo-Ortega F, Martinez-Flores A, Herrerias-Canedo T, Hernandez-Guerrero C. The predominant Th1 cytokine profile in maternal plasma of preeclamptic women is not reflected in the choriodecidual and fetal compartments. Journal of the Society for Gynecologic Investigation. 2005; 12(5):335-42. Epub 2005/06/28. [PubMed: 15979545]

63. Hennessy A, Pilmore HL, Simmons LA, Painter DM. A deficiency of placental IL-10 in preeclampsia. Journal of immunology. 1999; 163(6):3491-5. Epub 1999/09/08.

64. Dechend R, Homuth V, Wallukat G, Muller DN, Krause M, Dudenhausen J, et al. Agonistic antibodies directed at the angiotensin II, AT1 receptor in preeclampsia. Journal of the Society for Gynecologic Investigation. 2006; 13(2):79-86. Epub 2006/01/31. [PubMed: 16443499]

65. Kharfi A, Giguere Y, Sapin V, Masse J, Dastugue B, Forest JC. Trophoblastic remodeling in normal and preeclamptic pregnancies: implication of cytokines. Clin Biochem. 2003; 36(5):32331. Epub 2003/07/10. [PubMed: 12849862]

66. Yoshizumi M, Perrella MA, Burnett JC Jr, Lee ME. Tumor necrosis factor downregulates an endothelial nitric oxide synthase mRNA by shortening its half-life. Circulation research. 1993; 73(1):205-9. Epub 1993/07/01. [PubMed: 7685252]

67. Dekker GA, Kraayenbrink AA, Zeeman GG, van Kamp GJ. Increased plasma levels of the novel vasoconstrictor peptide endothelin in severe pre-eclampsia. European journal of obstetrics, gynecology, and reproductive biology. 1991; 40(3):215-20. Epub 1991/07/25.

68. Wang MX, Brown MA, Buddle ML, Carlton MA, Cario GM, Whitworth JA. Endothelin excretion in hypertensive pregnancy. Relationship to glomerular filtration rate, blood pressure, and sodium excretion. American journal of hypertension. 1994; 7(4 Pt 1):308-13. Epub 1994/04/01. [PubMed: 8031545]

69. Wilkins FC Jr, Alberola A, Mizelle HL, Opgenorth TJ, Granger JP. Systemic hemodynamics and renal function during long-term pathophysiological increases in circulating endothelin. Am J Physiol. 1995; 268(2 Pt 2):R375-81. Epub 1995/02/11. [PubMed: 7864231]

70. Alexander BT, Rinewalt AN, Cockrell KL, Massey MB, Bennett WA, Granger JP. Endothelin type a receptor blockade attenuates the hypertension in response to chronic reductions in uterine perfusion pressure. Hypertension. 2001; 37(2 Pt 2):485-9. Epub 2001/03/07. [PubMed: 11230323]

71. Yang X, Guo L, Li H, Chen X, Tong X. Analysis of the original causes of placental oxidative stress in normal pregnancy and pre-eclampsia: a hypothesis. J Matern Fetal Neonatal Med. 2012; 25(7): 884-8. Epub 2011/07/12. [PubMed: 21740314]

72. Kalyanaraman B. Teaching the basics of redox biology to medical and graduate students: Oxidants, antioxidants and disease mechanisms. Redox Biol. 2013; 1(1):244-57. Epub 2013/09/12. [PubMed: 24024158] 
73. Lappas M, Mitton A, Permezel M. In response to oxidative stress, the expression of inflammatory cytokines and antioxidant enzymes are impaired in placenta, but not adipose tissue, of women with gestational diabetes. J Endocrinol. 2010; 204(1):75-84. Epub 2009/10/17. [PubMed: 19833719]

74. Matsubara K, Matsubara Y, Hyodo S, Katayama T, Ito M. Role of nitric oxide and reactive oxygen species in the pathogenesis of preeclampsia. The journal of obstetrics and gynaecology research. 2010; 36(2):239-47. Epub 2010/05/25. [PubMed: 20492372]

75. Myatt L, Cui X. Oxidative stress in the placenta. Histochem Cell Biol. 2004; 122(4):369-82. Epub 2004/07/13. [PubMed: 15248072]

76. Yiyenoglu OB, Ugur MG, Ozcan HC, Can G, Ozturk E, Balat O, et al. Assessment of oxidative stress markers in recurrent pregnancy loss: a prospective study. Arch Gynecol Obstet. 2014; 289(6):1337-40. Epub 2013/12/04. [PubMed: 24297302]

77. Anumba DO, Robson SC, Boys RJ, Ford GA. Nitric oxide activity in the peripheral vasculature during normotensive and preeclamptic pregnancy. Am J Physiol. 1999; 277(2 Pt 2):H848-54. Epub 1999/08/13. [PubMed: 10444514]

78. Baylis C, Bloch J. Nitric oxide (NO) in renal physiology and pathophysiology. Nephrology, dialysis, transplantation : official publication of the European Dialysis and Transplant Association - European Renal Association. 1996; 11(10):1955-7. Epub 1996/10/01.

79. Alexander BT, Miller MT, Kassab S, Novak J, Reckelhoff JF, Kruckeberg WC, et al. Differential expression of renal nitric oxide synthase isoforms during pregnancy in rats. Hypertension. 1999; 33(1 Pt 2):435-9. Epub 1999/02/04. [PubMed: 9931143]

80. Baylis C, Mitruka B, Deng A. Chronic blockade of nitric oxide synthesis in the rat produces systemic hypertension and glomerular damage. The Journal of clinical investigation. 1992; 90(1): 278-81. Epub 1992/07/01. [PubMed: 1634615]

81. Hofmann SR, Ettinger R, Zhou YJ, Gadina M, Lipsky P, Siegel R, et al. Cytokines and their role in lymphoid development, differentiation and homeostasis. Curr Opin Allergy Clin Immunol. 2002; 2(6):495-506. Epub 2004/01/31. [PubMed: 14752332]

82. Chen LM, Liu B, Zhao HB, Stone P, Chen Q, Chamley L. IL-6, TNFalpha and TGFbeta promote nonapoptotic trophoblast deportation and subsequently causes endothelial cell activation. Placenta. 2010; 31(1):75-80. Epub 2009/12/02. [PubMed: 19948358]

83. Hung TH, Charnock-Jones DS, Skepper JN, Burton GJ. Secretion of tumor necrosis factor-alpha from human placental tissues induced by hypoxia-reoxygenation causes endothelial cell activation in vitro: a potential mediator of the inflammatory response in preeclampsia. The American journal of pathology. 2004; 164(3):1049-61. Epub 2004/02/26. [PubMed: 14982858]

84. Lockwood CJ, Yen CF, Basar M, Kayisli UA, Martel M, Buhimschi I, et al. Preeclampsia-related inflammatory cytokines regulate interleukin-6 expression in human decidual cells. The American journal of pathology. 2008; 172(6):1571-9. Epub 2008/05/10. [PubMed: 18467705]

85. LaMarca B, Parrish MR, Wallace K. Agonistic autoantibodies to the angiotensin II type I receptor cause pathophysiologic characteristics of preeclampsia. Gender medicine. 2012; 9(3):139-46. Epub 2012/04/14. [PubMed: 22498426]

86. Xia Y, Zhou CC, Ramin SM, Kellems RE. Angiotensin receptors, autoimmunity, and preeclampsia. Journal of immunology. 2007; 179(6):3391-5. Epub 2007/09/06.

87. Wallukat G, Homuth V, Fischer T, Lindschau C, Horstkamp B, Jupner A, et al. Patients with preeclampsia develop agonistic autoantibodies against the angiotensin AT1 receptor. The Journal of clinical investigation. 1999; 103(7):945-52. Epub 1999/04/09. [PubMed: 10194466]

88. Li C, Ansari R, Yu Z, Shah D. Definitive molecular evidence of renin-angiotensin system in human uterine decidual cells. Hypertension. 2000; 36(2):159-64. Epub 2000/08/19. [PubMed: 10948071]

89. Shah DM. The role of RAS in the pathogenesis of preeclampsia. Curr Hypertens Rep. 2006; 8(2): 144-52. Epub 2006/05/05. [PubMed: 16672148]

90. Merrill DC, Karoly M, Chen K, Ferrario CM, Brosnihan KB. Angiotensin-(1-7) in normal and preeclamptic pregnancy. Endocrine. 2002; 18(3):239-45. Epub 2002/11/27. [PubMed: 12450315]

91. AbdAlla S, Lother H, el Massiery A, Quitterer U. Increased AT(1) receptor heterodimers in preeclampsia mediate enhanced angiotensin II responsiveness. Nature medicine. 2001; 7(9):10039. Epub 2001/09/05. 
92. Quitterer U, Lother H, Abdalla S. AT1 receptor heterodimers and angiotensin II responsiveness in preeclampsia. Seminars in nephrology. 2004; 24(2):115-9. Epub 2004/03/16. [PubMed: 15017523]

93. Parrish MR, Murphy SR, Rutland S, Wallace K, Wenzel K, Wallukat G, et al. The effect of immune factors, tumor necrosis factor-alpha, and agonistic autoantibodies to the angiotensin II type I receptor on soluble fms-like tyrosine- 1 and soluble endoglin production in response to hypertension during pregnancy. American journal of hypertension. 2010; 23(8):911-6. Epub 2010/05/01. [PubMed: 20431529]

94. Novotny S, Wallace K, Herse F, Moseley J, Darby M, Heath J, et al. CD4 T Cells Play a Critical Role in Mediating Hypertension in Response to Placental Ischemia. Journal of hypertension : open access. 2013; 2 Epub 2013/06/17.

95. Aluvihare VR, Kallikourdis M, Betz AG. Regulatory T cells mediate maternal tolerance to the fetus. Nat Immunol. 2004; 5(3):266-71. Epub 2004/02/06. [PubMed: 14758358]

96. Saito S, Shiozaki A, Sasaki Y, Nakashima A, Shima T, Ito M. Regulatory T cells and regulatory natural killer (NK) cells play important roles in feto-maternal tolerance. Semin Immunopathol. 2007; 29(2):115-22. Epub 2007/07/12. [PubMed: 17621697]

97. Samstein RM, Josefowicz SZ, Arvey A, Treuting PM, Rudensky AY. Extrathymic generation of regulatory $\mathrm{T}$ cells in placental mammals mitigates maternal-fetal conflict. Cell. 2012; 150(1):29_ 38. Epub 2012/07/10. [PubMed: 22770213]

98. Toldi G, Svec P, Vasarhelyi B, Meszaros G, Rigo J, Tulassay T, et al. Decreased number of FoxP3+ regulatory T cells in preeclampsia. Acta Obstet Gynecol Scand. 2008; 87(11):1229-33. Epub 2008/11/20. [PubMed: 19016357]

99. Raghupathy R. Cytokines as key players in the pathophysiology of preeclampsia. Med Princ Pract. 2013; 22(Suppl 1):8-19. Epub 2013/08/21. [PubMed: 23949305]

100. Haimovici F, Hill JA, Anderson DJ. The effects of soluble products of activated lymphocytes and macrophages on blastocyst implantation events in vitro. Biology of reproduction. 1991; 44(1): 69-75. Epub 1991/01/01. [PubMed: 2015353]

101. Saito S, Sakai M, Sasaki Y, Tanebe K, Tsuda H, Michimata T. Quantitative analysis of peripheral blood Th0, Th1, Th2 and the Th1:Th2 cell ratio during normal human pregnancy and preeclampsia. Clinical and experimental immunology. 1999; 117(3):550-5. Epub 1999/09/01. [PubMed: 10469061]

102. Saito S, Tsukaguchi N, Hasegawa T, Michimata T, Tsuda H, Narita N. Distribution of Th1, Th2, and Th0 and the Th1/Th2 cell ratios in human peripheral and endometrial T cells. American journal of reproductive immunology. 1999; 42(4):240-5. Epub 1999/12/02. [PubMed: 10580606]

103. Saito S, Nakashima A, Shima T, Ito M. Th1/Th2/Th17 and regulatory T-cell paradigm in pregnancy. American journal of reproductive immunology. 2010; 63(6):601-10. Epub 2010/05/12. [PubMed: 20455873]

104. Cornelius DC, Lamarca B. TH17- and IL-17-mediated autoantibodies and placental oxidative stress play a role in the pathophysiology of pre-eclampsia. Minerva ginecologica. 2014; 66(3): 243-9. Epub 2014/06/28. [PubMed: 24971780]

105. Sakaguchi S, Yamaguchi T, Nomura T, Ono M. Regulatory T cells and immune tolerance. Cell. 2008; 133(5):775-87. Epub 2008/05/31. [PubMed: 18510923]

106. Sasaki Y, Sakai M, Miyazaki S, Higuma S, Shiozaki A, Saito S. Decidual and peripheral blood $\mathrm{CD} 4+\mathrm{CD} 25+$ regulatory $\mathrm{T}$ cells in early pregnancy subjects and spontaneous abortion cases. Molecular human reproduction. 2004; 10(5):347-53. Epub 2004/03/05. [PubMed: 14997000]

107. Liu X, Liu Y, Ding M, Wang X. Reduced expression of indoleamine 2,3-dioxygenase participates in pathogenesis of preeclampsia via regulatory T cells. Molecular medicine reports. 2011; 4(1): 53-8. Epub 2011/04/05. [PubMed: 21461563]

108. Santillan MK, Pelham CJ, Ketsawatsomkron P, Santillan DA, Davis DR, Devor EJ, et al. Pregnant mice lacking indoleamine 2,3-dioxygenase exhibit preeclampsia phenotypes. Physiol Rep. 2015; 3(1) Epub 2015/01/21.

109. Zenclussen AC, Fest S, Joachim R, Klapp BF, Arck PC. Introducing a mouse model for preeclampsia: adoptive transfer of activated Th1 cells leads to pre-eclampsia-like symptoms 
exclusively in pregnant mice. Eur J Immunol. 2004; 34(2):377-87. Epub 2004/02/10. [PubMed: 14768042]

110. Redman CW. Preeclampsia: a multi-stress disorder. Rev Med Interne. 2011; 32(Suppl 1):S41-4. Epub 2011/05/03. [PubMed: 21530020]

111. Li J, LaMarca B, Reckelhoff JF. A model of preeclampsia in rats: the reduced uterine perfusion pressure (RUPP) model. American journal of physiology Heart and circulatory physiology. 2012; 303(1):H1-8. Epub 2012/04/24. [PubMed: 22523250]

112. Alexander BT, Cockrell KL, Massey MB, Bennett WA, Granger JP. Tumor necrosis factor-alphainduced hypertension in pregnant rats results in decreased renal neuronal nitric oxide synthase expression. American journal of hypertension. 2002; 15(2 Pt 1):170-5. Epub 2002/02/28. [PubMed: 11863253]

113. Brown CE, Gant NF, Cox K, Spitz B, Rosenfeld CR, Magness RR. Low-dose aspirin. II. Relationship of angiotensin II pressor responses, circulating eicosanoids, and pregnancy outcome. American journal of obstetrics and gynecology. 1990; 163(6 Pt 1):1853-61. Epub 1990/12/01. [PubMed: 2256495]

114. Hladunewich M, Karumanchi SA, Lafayette R. Pathophysiology of the clinical manifestations of preeclampsia. Clinical journal of the American Society of Nephrology : CJASN. 2007; 2(3):5439. Epub 2007/08/19. [PubMed: 17699462]

115. Khalil RA, Granger JP. Vascular mechanisms of increased arterial pressure in preeclampsia: lessons from animal models. American journal of physiology Regulatory, integrative and comparative physiology. 2002; 283(1):R29-45. Epub 2002/06/19.

116. Crews JK, Herrington JN, Granger JP, Khalil RA. Decreased endothelium-dependent vascular relaxation during reduction of uterine perfusion pressure in pregnant rat. Hypertension. 2000; 35(1 Pt 2):367-72. Epub 2000/01/21. [PubMed: 10642326]

117. Alexander BT, Kassab SE, Miller MT, Abram SR, Reckelhoff JF, Bennett WA, et al. Reduced uterine perfusion pressure during pregnancy in the rat is associated with increases in arterial pressure and changes in renal nitric oxide. Hypertension. 2001; 37(4):1191-5. Epub 2001/04/17. [PubMed: 11304523]

118. Murphy JG, Herrington JN, Granger JP, Khalil RA. Enhanced [Ca2+]i in renal arterial smooth muscle cells of pregnant rats with reduced uterine perfusion pressure. American journal of physiology Heart and circulatory physiology. 2003; 284(1):H393-403. Epub 2002/10/22. [PubMed: 12388289]

119. Roberts L, LaMarca BB, Fournier L, Bain J, Cockrell K, Granger JP. Enhanced endothelin synthesis by endothelial cells exposed to sera from pregnant rats with decreased uterine perfusion. Hypertension. 2006; 47(3):615-8. Epub 2006/01/05. [PubMed: 16391174]

120. Sedeek M, Gilbert JS, LaMarca BB, Sholook M, Chandler DL, Wang Y, et al. Role of reactive oxygen species in hypertension produced by reduced uterine perfusion in pregnant rats. American journal of hypertension. 2008; 21(10):1152-6. Epub 2008/08/02. [PubMed: 18670418]

121. Gilbert JS, Babcock SA, Granger JP. Hypertension produced by reduced uterine perfusion in pregnant rats is associated with increased soluble fms-like tyrosine kinase- 1 expression. Hypertension. 2007; 50(6):1142-7. Epub 2007/10/10. [PubMed: 17923588]

122. Gilbert JS, Gilbert SA, Arany M, Granger JP. Hypertension produced by placental ischemia in pregnant rats is associated with increased soluble endoglin expression. Hypertension. 2009; 53(2):399-403. Epub 2008/12/17. [PubMed: 19075097]

123. Novotny SR, Wallace K, Heath J, Moseley J, Dhillon P, Weimer A, et al. Activating autoantibodies to the angiotensin II type I receptor play an important role in mediating hypertension in response to adoptive transfer of CD4+ T lymphocytes from placental ischemic rats. American journal of physiology Regulatory, integrative and comparative physiology. 2012; 302(10):R1197-201. Epub 2012/03/31.

124. Kleinewietfeld M, Hafler DA. Regulatory T cells in autoimmune neuroinflammation. Immunol Rev. 2014; 259(1):231-44. Epub 2014/04/10. [PubMed: 24712469]

125. Quinn KH, Lacoursiere DY, Cui L, Bui J, Parast MM. The unique pathophysiology of early-onset severe preeclampsia: role of decidual T regulatory cells. J Reprod Immunol. 2011; 91(1-2):7682. Epub 2011/07/26. [PubMed: 21782252] 
126. Ito T, Hanabuchi S, Wang YH, Park WR, Arima K, Bover L, et al. Two functional subsets of FOXP3+ regulatory T cells in human thymus and periphery. Immunity. 2008; 28(6):870-80. Epub 2008/06/03. [PubMed: 18513999]

127. Sasaki Y, Darmochwal-Kolarz D, Suzuki D, Sakai M, Ito M, Shima T, et al. Proportion of peripheral blood and decidual CD4(+) CD25(bright) regulatory T cells in pre-eclampsia. Clinical and experimental immunology. 2007; 149(1):139-45. Epub 2007/04/27. [PubMed: 17459078]

128. Munoz-Suano A, Hamilton AB, Betz AG. Gimme shelter: the immune system during pregnancy. Immunol Rev. 2011; 241(1):20-38. Epub 2011/04/15. [PubMed: 21488887]

129. von Rango U. Fetal tolerance in human pregnancy-a crucial balance between acceptance and limitation of trophoblast invasion. Immunol Lett. 2008; 115(1):21-32. Epub 2007/12/07. [PubMed: 18055021]

130. Jankovic D, Kullberg MC, Feng CG, Goldszmid RS, Collazo CM, Wilson M, et al. Conventional T-bet(+)Foxp3(-) Th1 cells are the major source of host-protective regulatory IL-10 during intracellular protozoan infection. The Journal of experimental medicine. 2007; 204(2):273-83. Epub 2007/02/07. [PubMed: 17283209]

131. Nevers T, Kalkunte S, Sharma S. Uterine Regulatory T cells, IL-10 and hypertension. American journal of reproductive immunology. 2011; 66(Suppl 1):88-92. Epub 2011/07/08. [PubMed: 21726343]

132. Shaw MH, Freeman GJ, Scott MF, Fox BA, Bzik DJ, Belkaid Y, et al. Tyk2 negatively regulates adaptive Th1 immunity by mediating IL-10 signaling and promoting IFN-gamma-dependent IL-10 reactivation. Journal of immunology. 2006; 176(12):7263-71. Epub 2006/06/06.

133. Heo YJ, Joo YB, Oh HJ, Park MK, Heo YM, Cho ML, et al. IL-10 suppresses Th17 cells and promotes regulatory $\mathrm{T}$ cells in the $\mathrm{CD} 4+\mathrm{T}$ cell population of rheumatoid arthritis patients. Immunol Lett. 2010; 127(2):150-6. Epub 2009/11/10. [PubMed: 19895848]

134. Murai M, Turovskaya O, Kim G, Madan R, Karp CL, Cheroutre H, et al. Interleukin 10 acts on regulatory $\mathrm{T}$ cells to maintain expression of the transcription factor Foxp3 and suppressive function in mice with colitis. Nat Immunol. 2009; 10(11):1178-84. Epub 2009/09/29. [PubMed: 19783988]

135. Jonuleit H, Schmitt E, Schuler G, Knop J, Enk AH. Induction of interleukin 10-producing, nonproliferating CD4(+) T cells with regulatory properties by repetitive stimulation with allogeneic immature human dendritic cells. The Journal of experimental medicine. 2000; 192(9): 1213-22. Epub 2000/11/09. [PubMed: 11067871]

136. Gu Y, Yang J, Ouyang X, Liu W, Li H, Yang J, et al. Interleukin 10 suppresses Th17 cytokines secreted by macrophages and T cells. Eur J Immunol. 2008; 38(7):1807-13. Epub 2008/05/29. [PubMed: 18506885]

137. Lochner M, Peduto L, Cherrier M, Sawa S, Langa F, Varona R, et al. In vivo equilibrium of proinflammatory IL-17+ and regulatory IL-10+ Foxp3+ RORgamma $t+$ T cells. The Journal of experimental medicine. 2008; 205(6):1381-93. Epub 2008/05/28. [PubMed: 18504307]

138. Simpson KL, Keelan JA, Mitchell MD. Labor-associated changes in interleukin-10 production and its regulation by immunomodulators in human choriodecidua. The Journal of clinical endocrinology and metabolism. 1998; 83(12):4332-7. Epub 1998/12/16. [PubMed: 9851773]

139. Chaouat G, Cayol V, Mairovitz V, Dubanchet S. Localization of the Th2 cytokines IL-3, IL-4, IL-10 at the fetomaternal interface during human and murine pregnancy and lack of requirement for Fas/Fas ligand interaction for a successful allogeneic pregnancy. American journal of reproductive immunology. 1999; 42(1):1-13. Epub 1999/08/03. [PubMed: 10429761]

140. Bennett WA, Lagoo-Deenadayalan S, Whitworth NS, Brackin MN, Hale E, Cowan BD. Expression and production of interleukin-10 by human trophoblast: relationship to pregnancy immunotolerance. Early Pregnancy. 1997; 3(3):190-8. Epub 1999/03/23. [PubMed: 10086069]

141. Kalkunte S, Lai Z, Tewari N, Chichester C, Romero R, Padbury J, et al. In vitro and in vivo evidence for lack of endovascular remodeling by third trimester trophoblasts. Placenta. 2008; 29(10):871-8. Epub 2008/09/09. [PubMed: 18775564]

142. Lai Z, Kalkunte S, Sharma S. A critical role of interleukin-10 in modulating hypoxia-induced preeclampsia-like disease in mice. Hypertension. 2011; 57(3):505-14. Epub 2011/01/26. [PubMed: 21263114] 
143. Makris A, Xu B, Yu B, Thornton C, Hennessy A. Placental deficiency of interleukin-10 (IL-10) in preeclampsia and its relationship to an IL10 promoter polymorphism. Placenta. 2006; 27(4-5): 445-51. Epub 2005/07/20. [PubMed: 16026832]

144. Rein DT, Breidenbach M, Honscheid B, Friebe-Hoffmann U, Engel H, Gohring UJ, et al. Preeclamptic women are deficient of interleukin-10 as assessed by cytokine release of trophoblast cells in vitro. Cytokine. 2003; 23(4-5):119-25. Epub 2003/09/12. [PubMed: 12967647]

145. Tinsley JH, Chiasson VL, Mahajan A, Young KJ, Mitchell BM. Toll-like receptor 3 activation during pregnancy elicits preeclampsia-like symptoms in rats. American journal of hypertension. 2009; 22(12):1314-9. Epub 2009/09/26. [PubMed: 19779466]

146. Chatterjee P, Chiasson VL, Kopriva SE, Young KJ, Chatterjee V, Jones KA, et al. Interleukin 10 deficiency exacerbates toll-like receptor 3-induced preeclampsia-like symptoms in mice. Hypertension. 2011; 58(3):489-96. Epub 2011/07/20. [PubMed: 21768525]

147. Markert UR, Fitzgerald JS, Seyfarth L, Heinzelmann J, Varosi F, Voigt S, et al. Lessons from reproductive immunology for other fields of immunology and clinical approaches. Chem Immunol Allergy. 2005; 89:169-79. Epub 2005/09/01. [PubMed: 16129963]

148. Zemse SM, Hilgers RH, Simkins GB, Rudic RD, Webb RC. Restoration of endothelin-1-induced impairment in endothelium-dependent relaxation by interleukin-10 in murine aortic rings. Can J Physiol Pharmacol. 2008; 86(8):557-65. Epub 2008/09/02. [PubMed: 18758504]

149. Tinsley JH, South S, Chiasson VL, Mitchell BM. Interleukin-10 reduces inflammation, endothelial dysfunction, and blood pressure in hypertensive pregnant rats. American journal of physiology Regulatory, integrative and comparative physiology. 2010; 298(3):R713-9. Epub 2010/01/08.

150. Cornelius DC, Amaral LM, Harmon AC, Wallace K, Thomas AJ, Campbell N, et al. An Increased Population of Regulatory T Cells Improves the Pathophysiology of Placental Ischemia in a Rat Model of Preeclampsia. American journal of physiology Regulatory, integrative and comparative physiology. 2015 ajpregu 00154 2015. Epub 2015/08/21.

151. Harmon A, Cornelius D, Amaral L, Paige A, Herse F, Ibrahim T, et al. IL-10 supplementation increases Tregs and decreases hypertension in the RUPP rat model of preeclampsia. Hypertension in pregnancy. 2015; 34(3):291-306. Epub 2015/05/23. [PubMed: 25996051]

152. Darby MM, Wallace K, Cornelius D, Chatman KT, Mosely JN, Martin JN, et al. Vitamin D Supplementation Suppresses Hypoxia-Stimulated Placental Cytokine Secretion, Hypertension and CD4 T Cell Stimulation in Response to Placental Ischemia. Medical journal of obstetrics and gynecology. 2013; 1(2) Epub 2013/09/23.

153. LaMarca B, Wallace K, Herse F, Wallukat G, Martin JN Jr, Weimer A, et al. Hypertension in response to placental ischemia during pregnancy: role of B lymphocytes. Hypertension. 2011; 57(4):865-71. Epub 2011/03/02. [PubMed: 21357287] 


\section{Summary Statement}

Not only have studies demonstrated that regulatory immune factors IL-10 and Tregs decrease the pathophysiology of PE through reducing AT1-AA, ROS and ET-1, but they suggest that boosting these factors during pregnancy can improve the outcome of placental ischemia. 


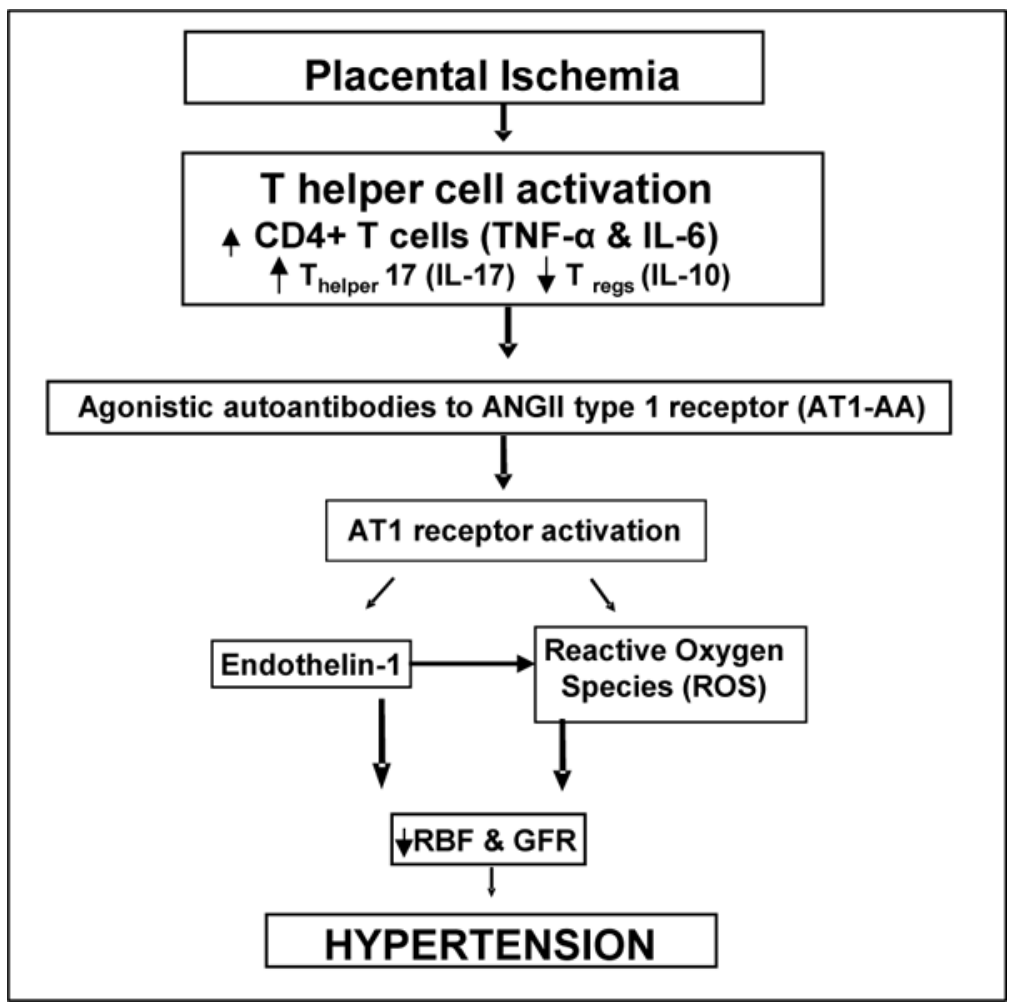

Figure.

CD4+ Tcells stimulated in response to placental ischemia exhibit an elevated TH17, decreased TREG ratio. Studies from our lab have shown that adoptive transfer of this ratio of CD4+ T cells is instrumental in causing AT1-AA, ET-1, ROS, and decreased renal excretory function, all important mediators of hypertension during PE, 